\title{
Moon Names of the Chippewa ${ }^{1}$
}

\section{Bernard C. Peters}

Keeping track of time by the Indians in the Great Lakes area was not as exact as among the European-Americans. The Indians had no method by which they could measure time except the daily movement of the sun, the phases of the moon, and the yearly cycle of seasons. They had no names for days; these were simply divided by the four easily recognized points: sunrise, mid-day, sunset, and midnight (Charlevoix 2:232). The passing of days was measured by the number of nights (or "sleeps") which had transpired. Travel distances, for instance, were not calculated by a linear measurement, but by the number of nights the traveller must sleep in making the trip (Grant 352). The Indians had no division of time corresponding to our week. Nor had they any names for the years. The passing of the years was reckoned by the number of winters which had occurred. Thus, an Indian's age was approximated by the number of winters he or she had survived.

The Indian year was subdivided into "moons." A good introduction to any discussion about the Indian habit of naming the moons is the following observation on the subject made by Pierre de Charlevoix during his 1720 visit to North America:

All of them reckon by lunar months; for the most part the year has but twelve; some, however, give it always thirteen. There are no great inconveniences attending this diversity amongst people who have no annals, and whose affairs do not depend on annual epochas. There is likewise a great variety in the seasons and months amongst them; because in all these countries the seasons for hunting and fishing, seedtime and harvest, the birth and fall of the leaf, the passage of particular beasts and birds, the time when the roe-bucks change their hair, and when different animals are in rut, serve to distinguish all these things which, besides, vary considerably in the different cantons. (2:232)

Thus, the Indians named the moons according to some event important to their way of life which had a regular and predictable occurrence in the environmen- 
tal setting in which they lived. ${ }^{2}$ And, as Charlevoix indicated, the exact events used to name the moons varied with the region and the way of life of the Indians. There was even some variation in moon names between the various bands within a single tribe because of their slightly different environments and food-getting practices (Baraga 2.221n). The purpose of this paper is to examine the names given to the moons by the Chippewa Indians who lived in the Lake SuperiorUpper Mississippi area, and to compare these to the moon names of some of their neighbors.

\section{Moons Of The Chippewa}

The Algonquian-speaking Chippewa who lived in the Lake SuperiorUpper Mississippi region obtained their livelihood primarily by hunting, fishing, and gathering. Their close relationship with the environment and its seasonal changes is clearly revealed by the names they gave to the moons. Table 1 presents five Chippewa moon name lists recorded by individuals who lived with or visited the tribe during the 1800 s and early 1900 s.

Most of the Chippewa moon names are easily explained because they describe events in the seasonal cycle of the region which may still be observed. For instance, May, now as then, is the month when the long northern winter finally releases its hold on the landscape and the wild flowers burst through last season's fallen leaves. And, depending on the latitude and proximity to Lake Superior, the leaves of the maple trees begin to change to yellow and red in late August or early September. October, now as then, is the month when the leaves begin to fall, and November the month when the rivers and lakes freeze over and the snow comes to stay.

Several of the Chippewa moon names relate to the gathering of wild vegetative products. This type of work was carried out by the women and supplied a large percentage of the family's food during and following the harvest period. For instance, through the summer months the women gathered large quantities of strawberries, raspberries, blueberries, and huckleberries (whortleberries) which were eaten fresh or dried for later use. These important food sources and activities account for the moon names corresponding, respectively, to June, July, and August. Wild rice was a very important fall and winter food for the Indians from Lake Michigan westward into Minnesota and northward around the western end of Lake Superior into Canada. As the moon name indicates, September was the usual month for harvesting wild rice, but in 
Table 1. Moon Names of the Chippewa ${ }^{3}$

\begin{tabular}{|c|c|c|c|c|}
\hline Baraga & Beltrami & $\begin{array}{l}\text { Kohl } \\
\text { January }\end{array}$ & Densmore & Kidder \\
\hline Spirit & Great Spirit & $\begin{array}{l}\text { Spirits } \\
\text { February }\end{array}$ & Big Spirit & Big Spirit \\
\hline Sucker; Eagle & Coming Eagles & $\begin{array}{l}\text { Suckers } \\
\text { March }\end{array}$ & Snow-Crust & Sucker or Carp \\
\hline $\begin{array}{l}\text { Crust on the Snow; } \\
\text { Wild Gooses [sic] }\end{array}$ & Hardened Snow & Snow-Crust & Broken-Snow-Shoe & $\begin{array}{l}\text { Crust on the } \\
\text { Snow }\end{array}$ \\
\hline & & April & & \\
\hline Snow-Shoe-Breakin & gg Snowshoes & $\begin{array}{l}\text { Breaking the } \\
\text { Snow-Shoes }\end{array}$ & Maple-Sugar Making & g $\begin{array}{c}\text { Snowshoe } \\
\text { Breaking }\end{array}$ \\
\hline & & May & & \\
\hline Flowers & Flowers & $\begin{array}{l}\text { Flowers } \\
\text { June }\end{array}$ & Flower & Flowers \\
\hline Strawberries & Strawberries & $\begin{array}{l}\text { Strawberry } \\
\text { July }\end{array}$ & Strawberry & Strawberries \\
\hline Raspberries & Blue Fruits & $\begin{array}{l}\text { Raspberry } \\
\text { August }\end{array}$ & Blueberry & Raspberries \\
\hline Blueberries & Yellow Leaves & $\begin{array}{l}\text { Whortleberry } \\
\text { September }\end{array}$ & Rice Moon & ttle Huckleberry \\
\hline $\begin{array}{l}\text { Gathering of } \\
\text { Wild Rice }\end{array}$ & Falling Leaves & $\overline{\text { Wild Rice }}$ & Shining Leaf & Big Huckleberry \\
\hline & & October & & \\
\hline Falling Leaves & Migratory Game & $\begin{array}{l}\text { Falling Leaf } \\
\text { November }\end{array}$ & Falling Leaf & Trout \\
\hline Freezing & Snow & $\begin{array}{l}\overline{\text { Freezing }} \\
\text { December }\end{array}$ & Freezing & Whitefish \\
\hline Little Spirit & Little Spirit & Little Spirits & Little Spirit & Little Spirit \\
\hline
\end{tabular}


some southern areas it was ripe by late August. Maple sugar was one of the most important wild products harvested by the Chippewa. It supplied a large part of their food sup-ply not only during the harvest period, but for several months thereafter. When the alternation of warm days and cool nights started the maple sap flowing, each family moved to its "sugar bush." Here the women and children would gather and boil the sap while the men hunted and fished nearby. Depending on location and the spring weather, the sugaring period usually occurred between late February and early April.

Several of the moon names of the Chippewa mark the migration of animals. February was (and is) the month when the bald eagles return to the Lake Superior area. Also in February, the suckers (called "carp" by the French) begin to leave the lakes and move up the streams under the ice. Their importance as a dependable food source to the Chippewa during a period of near starvation accounts for this moon name. The significance of fishing to the Chippewa of Lake Superior is revealed by the fact that the band living in the Marquette area called October and November, respectively, "Moon of Trout," and "Moon of Whitefish." It is during these months that the lake trout and whitefish come close to shore for spawning and can most easily be caught. The migration of vast numbers of waterfowl down the Mississippi River valley was of great importance to the Indians living along that flyway, hence the October moon name recorded by Beltrami.

The moon names concerning snow can be traced to the winter activities of these hunters of the northern forests. Like all the northern tribes whose winter food supply came mainly from the hunting of large animals, with the freeze-up of November the Chippewa moved to their winter hunting camps where they would remain until sugaring time. Each family unit had its own hunting territory; it would remain in a camp until the area was hunted out, then move to a new campsite within its territory.

During the winter hunt the main animals sought were moose, elk, and deer. These animals, especially the moose, were quite wary, and hunting success was poor until the snow deepened. If the snow cover was absent or thin, starvation occurred among the hunting bands. The relationship between snow conditions and well-being is well illustrated in the 1633-34 Relation of the Jesuit missionary Le Jeune. During that winter he lived with a hunting band of Indians in the deep forest north of the St. Lawrence. He reported that during the first part of the winter they resorted to eating branch ends, hides, and bark because the snow was too thin for successful hunting (Thwaites 7:145-47). Similar famine periods 
during poor snow conditions were reported by John Tanner while living with the Chippewa northwest of Lake Superior in the early 1800 s (180). When the snow finally became deep, the moose were easily tracked and could not so readily elude the hunters. While these conditions existed there was much feasting, and surplus meat was available for drying (Thwaites 7:179). ${ }^{4}$

The best time for killing moose and other heavy ungulates usually occurred in March. It was during this period that the alternation of thawing days and freezing nights, and perhaps some freezing rains, formed a crust on the snow. When this condition prevailed the moose and other hoofed animals were completely at the mercy of the Indians. The hunters on snowshoes and the hunting dogs would remain on top of the crust while the hoofed animals broke through. During such periods many animals could be taken because the hunters could walk right up to the animals and kill them with spear thrusts (Thwaites 6:295, 58:59; Tanner 187-88). The coureur de bois Pierre Esprit Radisson reported that such a crust on the snow saved him and the Indians he was living with south of Lake Superior from starvation during the Winter of 1661-62 (Adams 133).

This snow-crust condition could usually be counted on to occur in March, hence the most common name for that moon throughout the Lake SuperiorUpper Mississippi area was "Moon of the Crust on the Snow." A March 1807 account from the upper Mississippi well illustrates the ease of hunting under these conditions: "A crust formed on the snow, and all the young Indians and boys went off, and, for amusement, wantonly tomahawked every deer they could find, as the poor creatures, breaking through the crust, could not get out of the way (Anderson 159)."

With the higher sun and warmer weather of April, the snow crust softened and the hunters broke through. During this period of deteriorating snow the hunters' snowshoes were often broken, hence the most common name for the moon corresponding with April was "Snowshoe-Breaking Moon."

Explaining moon names which relate to observable environmental phenomena and to the Chippewa hunting and gathering activities is relatively easy. In the Lake Superior area the natural seasonal signposts are still recognized today, and there were numerous contemporary accounts which describe Chippewa economic operations. It is much more difficult, however, to account for the moon names corresponding to December and January, which appear to have their origin in Chippewa religion. This writer has found no firm evidence to account for these moon names. 
Several possible explanations exist, however. The account of John Tanner, who lived among the Chippewa in the late 1700s and early 1800s, offers one. When the Chippewa families were in their winter hunting camps they had numerous occasions to call on the Great Spirit. During November and December they still had some wild rice to augment the food obtained by hunting. But by January the rice had usually been consumed and the family was entirely dependent on the animals (mainly large animals such as moose, elk, and deer) that the hunters could kill. Often, however, the hunters did not kill anything for several days and starvation occurred. When this condition faced them the Great Spirit was called on for aid (Tanner $32,47,54,184,187$ ). The fact that January was the most difficult month for survival and, consequently, the month during which the Great Spirit was called on most often may be the reason it was called "The Moon of the Great Spirit."

Another possible explanation for the moon names associated with spirits relates to religious ceremonies which took place in late December or January. Henry Rowe Schoolcraft, while Indian agent at the American Sault in the 1820s, obtained from the local Chippewa the information that they had a "winter feast" to the Great Spirit held to instruct young people on proper behavior. During the ceremony an adult admonishes the juveniles to "be attentive and respectful to the aged, and adhere to their council; to be modest in their conduct; to be charitable and hospitable; and to fear and love the Great Spirit, who is the giver of life, and of every good gift." The youth were then given food and assured that if they behaved correctly the Great Spirit would always see that they had enough to eat (Mason 119-20).

There is also some evidence that the Chippewa had some sort of midwinter ceremony to celebrate the fact that the worst of the starving season was over. Among the Chippewa in the Rainy Lake area northwest of Lake Superior, the January moon was called "The Half of Winter Moon" (Grant 351). A missionary who spent the winter of 1862-63 among the Chippewa at L'Anse, Michigan, reported that the local chief invited her to the "winter feast" of the band, a week or so after Christmas, to celebrate the return of the sun from the south (Nelson 160). And a recent publication put together by the Chippewa of the Sault Ste. Marie area states that in the old times the local Indians held a "mid-winter" festival (O'gushnaan 6, 30). 


\section{Moon Names Of Indians To The South Of The Chippewa}

In a recent study of the relationship between Indians and the ecology of New England, William Cronon noticed a difference in the moon names between the hunting, fishing, gathering Indians of the north, and the agricultural southern tribes. He observed that while the Indians in Maine "named their lunar months in terms of seasonal changes in animal populations, referring to the egg laying of birds, the running of salmon, the molting of geese, the hibernation of bears, and so on," the farming tribes of southern New England named many of their moons for key periods in their crop-based economy (42-43). A similar modification of moon names occurred to the south of the Chippewa, among those tribes which obtained a large percentage of their food from crops.

A listing of the moon names of the Siouan-speaking Winnebago (Table 2), who lived in the Green Bay-Fox River area of Wisconsin, reveals the same thing noted by Cronon in New England. Among that tribe the moon names for the months May through September, instead of tracing the progress of the natural vegetation as do the Chippewa moon names, commemorate important events in their agricultural system.

The Winnebago lunar calendar reveals another characteristic about the relationship between moon names and the natural environment. Different environmental conditions resulted in different moon names. In the milder region in which the Winnebago lived, the seasonal changes were marked by different natural events and animals from those of the Chippewa. Snow and the fear of starvation no longer dominates the winter, and in this forest-prairie transition area deer were the most important food animal.

The moon names of the Mississippi River Sioux recorded by Beltrami in 1823 offers another comparison to those of the Chippewa. While the latter occupied the heavily-forested lake country of the Mississippi headwaters, the Sioux that Beltrami encountered inhabited the forest-prairie transition zone near the mouth of St. Peter's (Minnesota) River. ${ }^{6}$ Although these Sioux raised corn and other crops, hunting and gathering supplied most of their food, and agricultural moon names are absent. In the heavily forested region of the Chippewa there were few deer ("roebuck") or buffalo, while in the forest-prairie transition zone of the Sioux they were numerous, and their most important source of meat. While fishing was extremely important to the Chippewa, it was 
Table 2. Moon Names of the Winnebago. 5

\begin{tabular}{|c|c|c|}
\hline & Schoolcraft & Radin \\
\hline JANUARY & Little Bear's Moon & First Bear Moon \\
\hline FEBRUARY & Big Bear's Moon & Last Bear Moon \\
\hline MARCH & Coon Running Moon & Raccoon-Breeding Moon \\
\hline APRIL & Fish Running Moon & Fish Becoming Visible Moon \\
\hline MAY & Drying the Earth Moon & Drying-of-the-Earth Moon \\
\hline JUNE & $\begin{array}{l}\text { Digging the Ground } \\
\text { or Planting Corn }\end{array}$ & Digging Moon \\
\hline JULY & Hoeing Corn Moon & Cultivating Moon \\
\hline AUGUST & Corn Tasselling Moon & Tasselling Moon \\
\hline SEPTEMBER & $\begin{array}{l}\text { Corn Popping, or } \\
\text { Harvest Time Moon }\end{array}$ & Elk Whistling Moon \\
\hline OCTOBER & Elk Whistling Moon & $\begin{array}{l}\text { When the Deer Paw the } \\
\text { Earth Moon }\end{array}$ \\
\hline
\end{tabular}

relatively unimportant to the Sioux. That the two tribes utilized many of the same wild resources is revealed by the Sioux moon names for April, June, September, and October. The Sioux label for the March moon, "bad eyes," indicates that the long winter spent near a smoky fire had a detrimental effect on their eyes.

\section{NOTES}

1. A spelling of the tribe's name equally valid as the one used here is "Ojibwa." At first contact the French called them "Bouichtigouian," or "the people of the Sault"; hence in the accounts 
Table 3. Moon Names of the Sioux. ${ }^{7}$

\begin{tabular}{|llll|}
\hline JANUARY & valour & JULY & cherries \\
FEBRUARY & wild-cats & AUGUST & buffaloes \\
MARCH & bad eyes & SEPTEMBER & oats [wild rice] \\
APRIL & game & OCTOBER & second moon of oats \\
MAY & nests & NOVEMBER & roebuck \\
JUNE & strawberries & DECEMBER & budding of the \\
& & & roebuck's horn \\
\hline
\end{tabular}

of the fur traders they are often referred to as "Sauteurs," or "Sauteux." At the present time some of the Chippewa in the Lake Superior area are calling themselves "Anishinabe" ("The people").

2. This regularity of occurrence could be used in making future appointments, as the coureur de bois Nicolas Perrot did (sometime in the late 1600s) when he asssured the Outagami (Fox) that he would be at the mouth of the Wisconsin River at the time of the buffalo bull's rutting (Blair 2:117).

3. For convenience the moon names are arranged beginning with January. According to an informant of Densmore, the Chippewa in northern Minnesota began their year with the first full moon in the fall (119). Baraga gives no complete listing of moon names; each month's (moon's) name must be looked up separately. Baraga lived among the Chippewa on the south shore of Lake Superior between 1835 and 1853 . Beltrami (274) recorded these names in 1823 at St. Anthony Falls, the site of present-day Minneapolis. Kohl's list (120) was recorded in 1855 at La Pointe, in northern Wisconsin. Densmore (18) obtained these names in the early 1900 s from elderly Chippewa living in northern Minnesota and Wisconsin. Kidder (249), a native of Marquette, Michigan, conducted his interviews in the 1890 s while on summer vacation from Harvard.

4. Similar snow conditions and hunting results were also reported for the winter of 1644 (Thwaites 32:41, 269; see also Tanner 88).

5. Schoolcraft (4:239-40); Radin 76. January and February is the period when hibernating bears have their cubs.

6. For a discussion of the Sioux-Chippewa vegetative zones of occupation see Hickerson 7375.

7. Beltrami 274.

\section{Works Cited}

Adams, Arthur T., ed. The Exploration of Pierre Esprit Radisson. Minneapolis: Ross \& Haines, 1961. 
Anderson, Thomas G. "Narrative of Capt. Thomas G. Anderson." Collections of the State Historical Society of Wisconsin 9(1909): 137-206.

Baraga, R. R. Bishop. A Dictionary of the Otchipwe Language, Explained in English. 2 vols. 1878-80. Minneapolis: Ross \& Haines, 1973.

Beltrami, J. C. A Pilgrimage in America. 1878-80 Chicago: Quadrangle Books, 1962.

Blair, Emma Helen. The Indian Tribes of the Upper Mississippi Valley. 2 vols. Cleveland: Arthur H. Clark, 1911.

Charlevoix, Pierre de. Joumal of a Voyage to North America. 2 vols. London, 1761.

Cronon, William. Changes in the Land: Indians, Colonists, and the Ecology of New England. New York: Hill and Wang, 1983.

Densmore, Frances. Chippewa Customs. 1929. Minneapolis: Ross \& Haines, 1970.

Grant, Peter. "The Sauteux Indians, About 1804." Les Bourgeois de la Compagnie du Nord-Ouest, Ed. L. R. Masson. Vol.2. New York: Antiquarian P, 1960.307-66.2 vols. Hickerson, Harold. The Chippewa and Their Neighbors: A Study in Ethnohistory. New York: Holt, Rinehart and Winston, 1970.

Kidder, Homer Huntington. "Ojibwa Myths and Halfbreed Tales Related by Charles and Charlotte Kobawagam and Jacques Le Pique, 1893-1895," Ms. located in the collection of the American Philosophical Society, Philadelphia.

Kohl, Johann Georg. Kitchi-Gami: Wanderings Round Lake Superior. London: Chapman and Hall, 1860.

Mason, Philip P., ed. Schoolcraft: The Literary Voyager or Muzzengiegun. East Lansing: Michigan State UP, 1962.

Nelson, J. Raleigh. Lady Unafraid. Caldwell, Idaho: Caxton Printers, 1951.

O'gushnaan - Our Mother: A Collection of Writings by and About Anishinabe of the Eastern Upper Peninsula of Michigan. Sault Ste. Marie, Ontario: Wayne Webb, 1982.

Radin, Paul. The Winnebago Tribe. Lincoln: U of Nebraska P, 1970.

Schoolcraft, Henry R. Information Respecting the History, Condition, and Prospects of the Indian Tribes of the United States. 6 vols. Philadelphia. $1852-57$.

Tanner, John. A Narrative of the Captivity and Adventures of John Tanner. 1830. Ed. Edwin James. Minneapolis: Ross \& Haines, 1956.

Thwaites, Reuben Gold, ed. The Jesuit Relations and Allied Documents. 73 vols. New York: Pageant Book Company, 1959. 